\title{
A Novel Actinomycete from Sugar-cane Bagasse: Saccharopolyspora hirsuta gen. et sp. nov.
}

\author{
By J. LACEY \\ Rothamsted Experimental Station, Harpenden AL5 $2 J Q$, Hertfordshire \\ AND M. GOODFELLOW \\ Microbiology Department, Medical School, The University of Newcastle, \\ Newcastle upon Tyne NEI $7 R U$
}

(Received I I October 1974; revised 9 December 1974)

\section{SUMMARY}

A new species of nocardioform actinomycete isolated from spontaneously heated sugar-cane bagasse is described as Saccharopolyspora hirsuta gen. et sp. nov. It has affinities with species of both Nocardia and Actinomadura but can be distinguished from both genera by its morphology, sporulation, wall and lipid analyses, antibiotic resistance, degradation and carbon utilization tests.

\section{INTRODUCTION}

Sugar-cane bagasse is the squashed chopped fibre left after sugar is extracted from the cane. Initially it contains $50 \%$ water and 3 to $5 \%$ sugar. When stacked in bales it heats rapidly, which favours the growth of thermophilic fungi and actinomycetes (Lacey, 1974). One such actinomycete, Thermoactinomyces sacchari, can cause the respiratory disease bagassosis, a form of extrinsic allergic alveolitis (Lacey, I97I $b$ ). Often, $T$. sacchari was accompanied by an actinomycete which grew well at $40{ }^{\circ} \mathrm{C}$ to produce white aerial mycelium, with bead-like chains of spores enclosed in a characteristic hairy sheath. This unidentified actinomycete had fragmenting mycelium and type IV walls (Becker, Lechevalier \& Lechevalier, 1965), and degraded casein, tyrosine, hypoxanthine and xanthine; it was therefore assigned provisionally to the genus Nocardia (Lacey, 1974). However, isolates have now been compared with representative cultures of allied taxa and seem to represent a homogeneous and distinct taxon. In this paper we describe properties of this organism and propose the name Saccharopolyspora hirsuta.

\section{METHODS}

Cultures. Colonies of Saccharopolyspora hirsuta were isolated from airborne bagasse dust by using a wind-tunnel technique (Lacey, I97I $a$, I974); the Andersen sampler was loaded with Petri dishes containing half-strength nutrient agar medium with $50 \mu \mathrm{g}$ actidione/ml (Gregory $\&$ Lacey, 1963). Twenty-five $S$. hirsuta isolates from West Indian bagasse samples were compared with cultures representing the genera Nocardia, Actinomadura, Mycobacterium and 'Mycobacterium' rhodochrous. Detailed histories of most of these strains have been given (Goodfellow, I97I; Goodfellow, Fleming \& Sackin, 1972; Goodfellow \& Orchard, 1974; Goodfellow et al. 1974).

All cultures were maintained on yeast extract-malt extract agar (Pridham et al. 1957) or V-8 vegetable juice agar (Corbaz, Gregory \& Lacey, 1963). 
Morphological examination. Colonies growing on agar plates were examined microscopically, and substrate and aerial mycelium were classified as by Cross, Maciver \& Lacey (I968). Growth was compared on glycerol-asparagine (Pridham \& Lyons, I96I), halfstrength nutrient, V-8 juice, and yeast extract-malt extract agars after incubation at 37 or $40{ }^{\circ} \mathrm{C}$. Colour descriptions are those of Ridgway (I9I2).

Electron microscopy. Spores were examined by transmission and scanning electron microscopy. Spores and hyphae for sectioning were grown on cellophane (Lacey \& Vince, I97I) on half-strength nutrient agar. Portions of cellophane, bearing growth, were removed and fixed intact for $5 \mathrm{~h}$ in either $2.5 \%(\mathrm{v} / \mathrm{v})$ glutaraldehyde or $4 \%(\mathrm{v} / \mathrm{v})$ formaldehyde, both in $0.05 \mathrm{M}$-cacodylate buffer at $\mathrm{pH} 7$, rinsed in buffer alone, then placed in $2 \%(\mathrm{w} / \mathrm{v})$ osmium tetroxide overnight. After rinsing in buffer, they were dehydrated in acetone and embedded in Epon. Sections were stained with $2 \%(w / v)$ uranyl acetate followed by Reynold's lead citrate.

Degradation tests. Cultures were examined by using the methods of Goodfellow (I97I) with one addition. A dense inoculum of each culture was streaked across a plate containing $0.3 \%$ (w/v) elastin (Sigma) in the basal medium described by Gordon (1967). After 7 and I4 days' incubation, each plate was observed for the disappearance of the insoluble elastin underneath and around the growth.

Antibiotic sensitivity studies. Organisms were tested for their in vitro susceptibility to I 2 anti-microbial agents (Table 2) by using an impregnated filter-paper disc method (Goodfellow \& Orchard, I974).

Organic compounds as sole sources of carbon. Test strains were examined for their ability to grow on 37 carbon sources (Table 3) by using the media and methods described by Goodfellow (I97I).

Analysis for lipid LCN-A. Cultures grown on modified Sauton's medium were analysed for lipid LCN-A (Mordarska, Mordarski \& Goodfellow, 1972). These lipids, characteristic of Nocardia species and 'Mycobacterium' rhodochrous, have been shown to be free nocardomycolic acids (Goodfellow et al. 1973; Minnikin, Patel \& Goodfellow, I974). Whole organism methanolysates of four isolates from bagasse were also examined for the presence of bound nocardomycolic acids and mycolic acids sensu stricto (i.e. characteristic of Mycobacterium; Lechevalier, Lechevalier \& Horan, I973).

\section{RESULTS}

Isolates from bagasse differed little from one another in appearance, wall composition, antibiotic resistance, degradation and carbon utilization tests, but were distinct from all other species with which they were compared. The differences were sufficiently great to necessitate the creation of a new genus, Saccharopolyspora, containing the one species $S$. hirsuta. These new taxa are described below.

\section{Saccharopolyspora Lacey \& Goodfellow gen. nov.}

Aerobic, Gram-positive, non-acid-fast actinomycetes with fragmenting substrate mycelium. Aerial mycelium segmenting into spores contained within a sheath. Wall composition type IV (Becker et al. 1965).

Saccharum, referring to the origin of isolates from sugar cane bagasse; polyspora, many spored.

Type species: Saccharopolyspora hirsuta Lacey \& Goodfellow sp. nov. 
Saccharopolyspora hirsuta gen. et sp. nov.
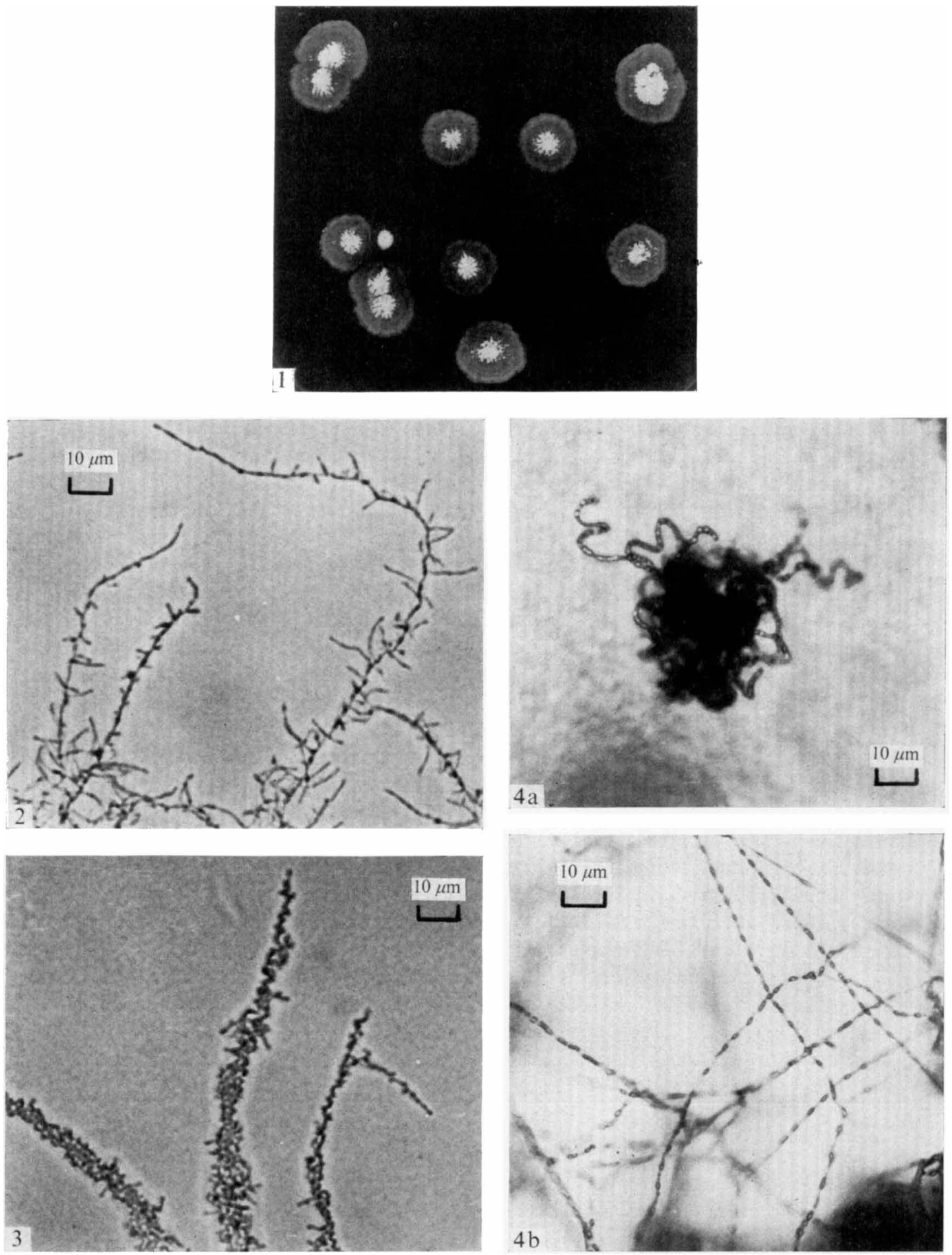

Fig. I. Colonies of $S$. hirsuta. Half-strength nutrient agar, incubation $37^{\circ} \mathrm{C}$.

Fig. 2. Morphology of substrate mycelium. Glycerol-asparagine agar, incubation $40^{\circ} \mathrm{C}$.

Fig. 3. Fragmentation of substrate mycelium. Glycerol-asparagine agar, incubation $40^{\circ} \mathrm{C}$.

Fig. 4. Spore chains on aerial mycelium showing tufted appearance, and (a) typical curved chains (half-strength nutrient agar, incubation $40^{\circ} \mathrm{C}$ ) and (b) typical straight chains (V-8 juice agar, incubation $37^{\circ} \mathrm{C}$ ) sometimes found. 


\section{Description of Saccharopolyspora hirsuta Lacey \& Goodfellow sp. nov.}

Hirsuta, hairy, referring to the spore surface characteristic.

Type strain AI 43 .

Colonies were thin, raised or convex and usually slightly wrinkled. The substrate mycelium was colourless to cartridge buff and usually mucoid or gelatinous. Sparse white aerial mycelium was produced in tufts at the centres of the colonies (Fig. I). A yellow soluble pigment was produced on yeast extract-malt extract agar.

Substrate hyphae were 0.4 to $0.6 \mu \mathrm{m}$ diam, branched, and usually unfragmented at the edge of the colony (Fig. 2). Occasionally, typical nocardioform fragmentation into rodshaped elements was found at the growing margin (Fig. 3) and more often in older parts of the colony. The substrate hyphae occasionally resembled sporing aerial hyphae, perhaps because aerial hyphae had collapsed on to the surface of the colony.

Aerial hyphae were 0.5 to $0.7 \mu \mathrm{m}$ in diameter, and characteristically segmented into beadlike chains of spores often separated by lengths of 'empty' hyphae most closely resembling those of Actinomadura dassonvillei (Brocq Rousseau) Lechevalier' \& Lechevalier. Usually the spore chains formed loops or loose spirals, but sometimes long straight chains were found between tufts of aerial mycelium (Fig. $4 \mathrm{a}, \mathrm{b}$ ).

Spores were round to oval, $0 \cdot 7-\mathrm{I} \cdot 3 \times 0.5-0 \cdot 7 \mu \mathrm{m}$, and covered by a sheath carrying tufts of long straight or curved hairs (Fig. 5 a). The morphology of the hairs is better seen on lengths of empty sheath (Fig. 5 b) or by scanning electron microscopy (Fig. 6). The sheath surface between the tufts of hairs appeared smooth.

Fine structure. Hyphae (Fig. 7) were bounded by a wall 22 to $30 \mathrm{~nm}$ thick. The cytoplasm, enclosed in a typical unit membrane, was granular with diffuse, axial nuclear material. Electron-transparent vacuoles, up to $0.3 \mu \mathrm{m}$ diam and resembling lipid accumulations in other nocardioform actinomycetes, were sometimes abundant, together with occasional electron-dense granules, up to $0 \cdot \mathrm{I} \mu \mathrm{m}$ diam, resembling polyphosphate or metachromatic granules. Lamellar mesosomes up to $0.25 \mu \mathrm{m}$ diam were sometimes seen. Septation occurred by a double ingrowth of the wall leading to fragmentation.

Spores were contained within a sheath 18 to $36 \mathrm{~nm}$ thick, carrying tufts of structureless hairs. These tufts were triangular at the base ( 0.2 to $0.3 \mu \mathrm{m}$ across) extending into an apical filament about $20 \mathrm{~nm}$ diam. Occasionally there was unidentified material (Fig. 8) within the sheath between spores, but this area usually appeared empty. The walls of spores were uniformly thickened to 50 to $60 \mathrm{~nm}$, but their internal structure was similar to hyphae except that there were few vacuoles (Fig. 9).

Temperature requirements. Most isolates grew at 25 and $50{ }^{\circ} \mathrm{C}$ with an optimum at about 37 to $40{ }^{\circ} \mathrm{C}$. No growth occurred at $10{ }^{\circ} \mathrm{C}$. Most aerial mycelium was produced close to the optimum.

Hydrolysis tests. Saccharopolyspora hirsuta isolates gave positive reactions in most tests

Fig. 5. Electron micrographs of (a) spore chains and (b) empty sheath showing tufted production of hairs.

Fig. 6. Scanning electron micrograph of spore chain.

Fig. 7. Longitudinal section of hypha, showing possible lipid accumulations (L) and polyphosphate granules (P).

Fig. 8. Longitudinal section of spore chain showing spores apparently separated by cytoplasm-like material.

Fig. 9. Longitudinal section of mature spore chain showing sheath and hair bases. 

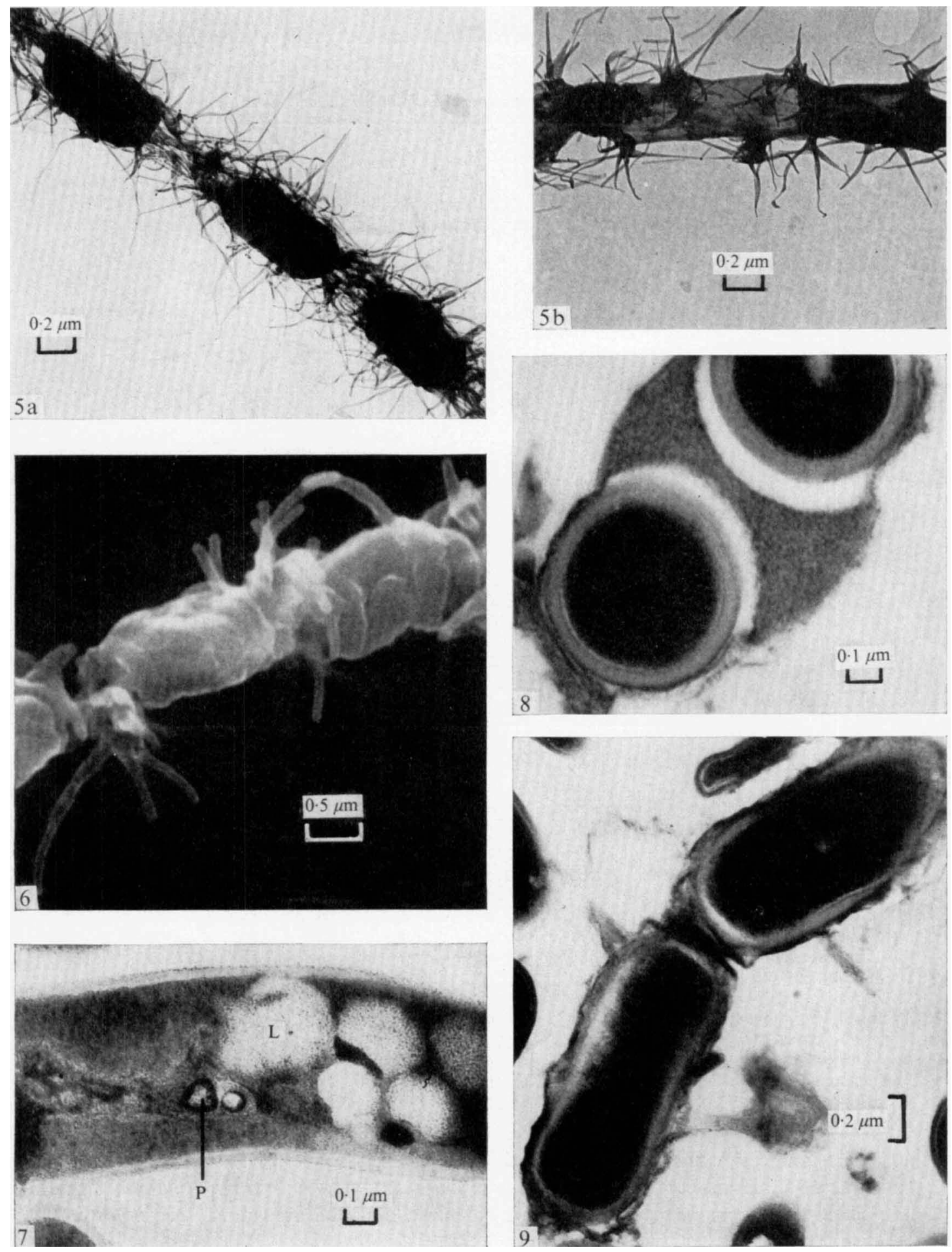
Table I. Abilities of Saccharopolyspora hirsuta and other nocardioform taxa to degrade different substrates

Percentage of isolates degrading substrate

\begin{tabular}{|c|c|c|c|c|c|c|c|c|c|}
\hline & $\begin{array}{l}\text { Nocardia } \\
\text { asteroides }\end{array}$ & $\begin{array}{c}N . \\
\text { brasili- } \\
\text { ensis }\end{array}$ & $\begin{array}{c}N . \\
\text { caviae }\end{array}$ & $\begin{array}{c}\text { Saccharo- } \\
\text { polyspora } \\
\text { hirsuta }\end{array}$ & $\begin{array}{c}\text { Actino- } \\
\text { madura } \\
\text { dasson- } \\
\text { villei }\end{array}$ & $\begin{array}{c}A . \\
\text { madurae }\end{array}$ & $\begin{array}{c}A . \\
\text { pelletieri }\end{array}$ & $\begin{array}{c}\text { 'Myco- } \\
\text { bac- } \\
\text { terium' } \\
\text { rhodo- } \\
\text { chrous }\end{array}$ & $\begin{array}{l}\text { Myco- } \\
\text { bac- } \\
\text { terium }\end{array}$ \\
\hline $\begin{array}{c}\text { Total isolates } \\
\text { examined }\end{array}$ & ... $8 \mathrm{I}$ & I 8 & 15 & 25 & 6 & 22 & I I & 146 & 64 \\
\hline \multicolumn{10}{|l|}{ Substrate } \\
\hline Adenine & 0 & 0 & 0 & 100 & 100 & 0 & 0 & 49 & 0 \\
\hline Aesculin & 100 & 100 & 100 & 100 & 0 & 100 & 0 & 90 & 62 \\
\hline Casein & I & 100 & 0 & 100 & $8 \mathrm{r}$ & 100 & 0 & 0 & 2 \\
\hline Elastin & 0 & 100 & 0 & 100 & 100 & 100 & 100 & 0 & 0 \\
\hline Hypoxanthine & 0 & 100 & 93 & 100 & 100 & $8 \mathrm{I}$ & 100 & 0 & 0 \\
\hline Keratin & 0 & 100 & 0 & 100 & 100 & $8 \mathrm{r}$ & 100 & 0 & 0 \\
\hline Tyrosine & I & 94 & 0 & 100 & 100 & 90 & 100 & 60 & 0 \\
\hline Urea & 98 & 100 & 100 & 100 & 33 & 0 & 9 & 75 & 66 \\
\hline Xanthine & 0 & 0 & 100 & 100 & 100 & 0 & 0 & 0 & 0 \\
\hline Xylan & 0 & 0 & 0 & 0 & 0 & 0 & 0 & o & 0 \\
\hline \multicolumn{10}{|l|}{ Resistance to } \\
\hline lysozyme $(\%)$ & 100 & 100 & 100 & 0 & 0 & 0 & 0 & 14 & 14 \\
\hline
\end{tabular}

Table 2. Susceptibility of Saccharopolyspora hirsuta and other nocardioform taxa to anti-microbial agents impregnated in filter-paper discs

[Filter-paper discs were soaked in anti-microbial agent at the concentrations $(\mu \mathrm{g} / \mathrm{ml})$ given in parentheses.

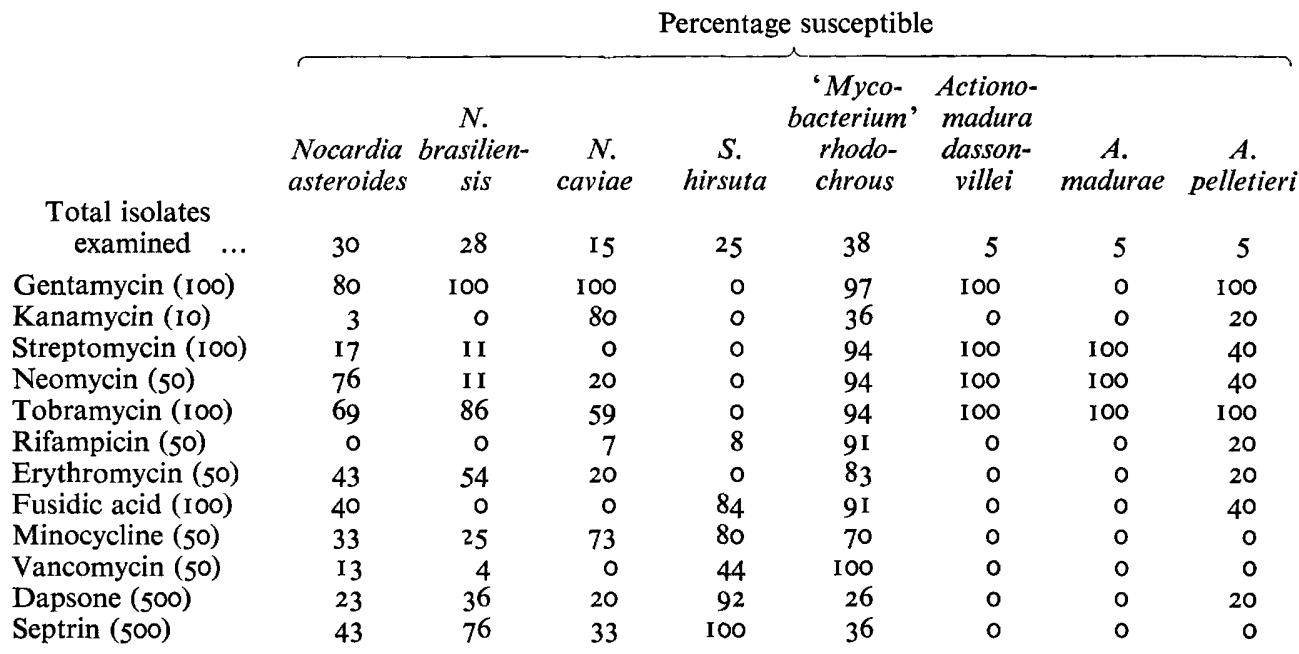

(Table I) and can readily be distinguished from Nocardia species by their ability to degrade adenine and their susceptibility to lysozyme. Degradation of elastin by $S$. hirsuta suggests possible pathogenic properties since all Nocardia and Actinomadura species with this ability can cause mycetoma.

Antibiotic-sensitivity studies. The antibiotic-sensitivity pattern distinguished S. hirsuta from the other nocardioform taxa studied (Table 2). Saccharopolyspora hirsuta showed 
Table 3. Suitability of sole carbon sources for energy and growth

Percentage of isolates growing on carbon source

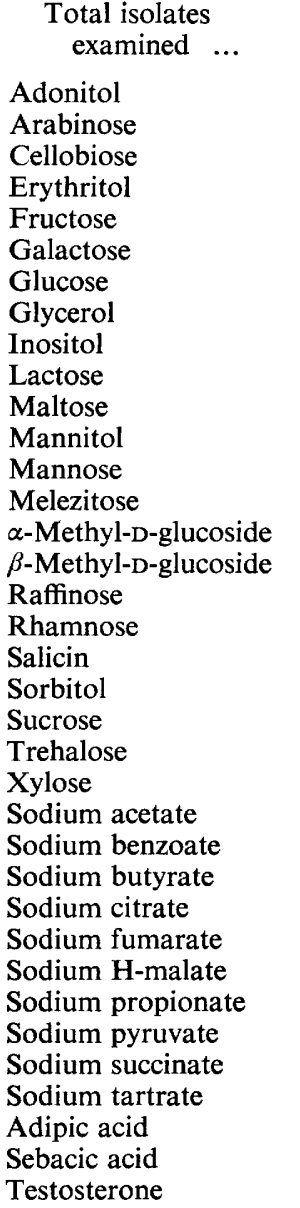

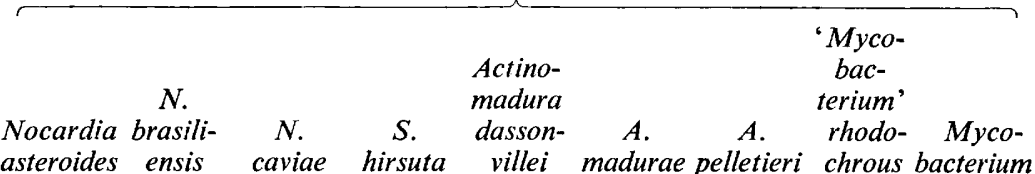

$\begin{array}{rrrrrrrrr}8 \mathrm{I} & \mathrm{I} 8 & 15 & 25 & 6 & 22 & \mathrm{II} & 146 & 64 \\ 0 & 0 & 0 & 100 & 0 & 72 & 0 & 0 & 0 \\ 0 & 0 & 0 & 0 & 66 & 59 & 63 & \mathrm{I} & 59 \\ 8 & 0 & 0 & 100 & 83 & 14 & 0 & 0 & 20 \\ 0 & 0 & 0 & 100 & 0 & 0 & 0 & 0 & - \\ 96 & 9 \mathrm{I} & 100 & 100 & 100 & 59 & 0 & 99 & 77 \\ 20 & 9 \mathrm{I} & 0 & 100 & 66 & 68 & 63 & 1 & 2 \mathrm{I} \\ 99 & 100 & 100 & 100 & 100 & 100 & 100 & 100 & 97 \\ 92 & 94 & 93 & 100 & 100 & 72 & 45 & 98 & 72 \\ 4 & 93 & 93 & 100 & 33 & 0 & 0 & 8 & 56 \\ 0 & 0 & 0 & 100 & 0 & 0 & 0 & 0 & 2 \\ 60 & 55 & 13 & 100 & 100 & 77 & 18 & 84 & 56 \\ 37 & 84 & 100 & 100 & 100 & 72 & 9 & 87 & 75 \\ 48 & 66 & 25 & 100 & 100 & 50 & 9 & 98 & 80 \\ 0 & 0 & 0 & 0 & 0 & 0 & 0 & 6 & 0 \\ 0 & 0 & 0 & 100 & 17 & 0 & 0 & 0 & - \\ 7 & 6 & 93 & 100 & - & - & - & 4 & - \\ 0 & 0 & 0 & 100 & 0 & 0 & 0 & 0 & 0 \\ 30 & 0 & 0 & 100 & 66 & 72 & 9 & 0 & 38 \\ 12 & 18 & 13 & 0 & 33 & 0 & 0 & 27 & 0 \\ 3 & 0 & 0 & 100 & 0 & 14 & 0 & 85 & 35 \\ 49 & 83 & 50 & 100 & 100 & 14 & 0 & 98 & 34 \\ 25 & 100 & 27 & 100 & 33 & 95 & 90 & 88 & 41 \\ 4 & 0 & 0 & 100 & 83 & 90 & 0 & 1 & 53 \\ 100 & 100 & 100 & 100 & 100 & 8 \mathrm{I} & 100 & 99 & 80 \\ 10 & 0 & 0 & 100 & 0 & 0 & 0 & 69 & 44 \\ 100 & 100 & 100 & 100 & 100 & 72 & 100 & 96 & 80 \\ 44 & 88 & 20 & 100 & 100 & 45 & 90 & 88 & 32 \\ 84 & 44 & 100 & 100 & - & - & - & 94 & -60 \\ 100 & 100 & 100 & 100 & 100 & 68 & 100 & 96 & 60 \\ 96 & 100 & 100 & 80 & 83 & 68 & 100 & 97 & 85 \\ 96 & 100 & 100 & 88 & 83 & 50 & 100 & 90 & 24 \\ 92 & 88 & 100 & 100 & 100 & 81 & 63 & 97 & 3 \\ 0 & 0 & 0 & 0 & 0 & 0 & 0 & 15 & 0 \\ 2 & 0 & 0 & 0 & 0 & 0 & 0 & 88 & 6 \\ 96 & 100 & 100 & 100 & 83 & 0 & 90 & 80 & 42 \\ 82 & 0 & 100 & 100 & 33 & 0 & 0 & 7 \mathrm{I} & 32\end{array}$

remarkable resistance to the anti-microbials tested, except large concentrations of septrin, dapsone, minocycline and fusidic acid.

Organic compounds as sole sources of carbon for energy and growth. Saccharopolyspora hirsuta isolates were extremely versatile and utilized 32 of 37 carbon sources tested (Table 3 ). The pattern of utilization distinguished them from other taxa.

Analysis for lipid LCN-A. Lipid LCN-A was detected in all of the Nocardia and ' $M y c o$ bacterium' rhodochrous cultures tested but not in S. hirsuta, Mycobacterium spp. or Actinomadura spp. Bound mycolic acids were not detected in the four cultures of $S$. hirsuta examined.

Differentiation from related taxa. Table 4 lists characters by which $S$. hirsuta may be 
Table 4. Differentiation of Saccharopolyspora from allied taxa

\begin{tabular}{|c|c|c|c|c|c|}
\hline & Nocardia & $\begin{array}{l}\text { Saccharo- } \\
\text { polyspora }\end{array}$ & Actinomadura & $\begin{array}{c}\text { 'Myco- } \\
\text { bacterium' } \\
\text { rhodochrous }\end{array}$ & $\begin{array}{c}\text { Myco- } \\
\text { bacterium }\end{array}$ \\
\hline \multicolumn{6}{|l|}{ Morphological characters } \\
\hline Aerial hyphae & + & + & + & - & - \\
\hline Arthrospores & $\pm^{*}$ & + & \pm & - & - \\
\hline Spore surface & Smooth & Hairy & $\begin{array}{l}\text { Smooth or } \\
\text { warty }\end{array}$ & No spores & No spores \\
\hline Acid-fast stain & \pm & - & - & \pm & + \\
\hline \multicolumn{6}{|l|}{ Chemical characters } \\
\hline Wall type & IV & IV & III & IV & IV \\
\hline Nocardomycolic acid & $+\dagger$ & - & - & + & - \\
\hline Mycolic acid sensu stricto & - & - & - & - & + \\
\hline \multicolumn{6}{|l|}{ Hydrolysis tests } \\
\hline Casein & \pm & + & + & - & - \\
\hline Elastin & \pm & + & + & - & - \\
\hline \multicolumn{6}{|l|}{ Sole carbon sources } \\
\hline Cellobiose & - & + & - & - & - \\
\hline Erythritol & - & + & - & - & NR \\
\hline Lactose & - & + & - & - & - \\
\hline$\alpha$-Methyl-D-glucoside & - & + & - & - & NR \\
\hline Raffinose & - & + & - & - & - \\
\hline Sorbitol & - & + & - & + & \pm \\
\hline Benzoate & - & + & - & \pm & \pm \\
\hline \multicolumn{6}{|l|}{ Resistance to } \\
\hline Lysozyme & + & - & - & - & - \\
\hline Gentamycin & - & + & \pm & - & \pm \\
\hline Rifampicin & + & + & + & - & + \\
\hline Streptomycin & + & + & - & + & \pm \\
\hline
\end{tabular}

+ , Character positive in more than $80 \%$ of isolates; - , character negative in more than $80 \%$ of isolates; \pm , character variable, occurring in $2 \mathrm{I}$ to $79 \%$ of isolates; NR, no result.

* Whether or not arthrospores are considered to occur in Nocardia depends on the interpretation placed on fragmenting aerial hyphae.

$\uparrow$ Nocardia autotrophica not included.

differentiated from related taxa. Characters positive in more than $80 \%$ of strains are designated + , and those positive in fewer than $20 \%$ of strains are designated - Saccharopolyspora hirsuta may be differentiated from all related taxa by their characteristic spores and the pattern of utilization of organic compounds as sole carbon sources; from Nocardia by their lack of nocardomycolic acids, susceptibility to lysozyme and resistance to gentamycin; from Actinomadura by wall composition; and from Mycobacterium and 'Mycobacterium' rhodochrous by the presence of aerial mycelium and spores, lack of mycolic or nocardomycolic acids, and antibiotic resistance.

Distribution. Saccharopolyspora hirsuta was frequently isolated from bagasse samples, although usually in small numbers (Lacey, 1974), and was present in samples originating from Puerto Rico, Trinidad, Jamaica and India. It was accompanied by thermophilic fungi and other actinomycetes, indicating spontaneous heating of the bagasse during storage.

Cultures of the type strain are deposited with the National Collection of Industrial Bacteria (NCIBI I079), Centraalbureau voor Schimmelcultures (CBS420.74), American Type Culture Collection (ATCC27875), Northern Regional Research Laboratories, Peoria, Illinois (NRRL B-5792) and the Kaken Chemical Co (KCC A-OI70). 


\section{DISCUSSION}

Recently, many novel actinomycetes have been isolated from different habitats. Some fit in established genera (Lacey, 197I $b$; Nonomura, 1974) but the others have required new genera (Gledhill \& Casida, I969; Nonomura \& Ohara, 197I $a$ ), increasing the number recognized from 35 (Williams, Davies \& Cross, 1968) to about 60 (Krassilnikov, 1970; Cross \& Goodfellow, 1973). A classification should be practical and new taxa should not be proposed until it is certain that they do not fit those already established. However, poor descriptions and lack of a generally accepted classification may make this difficult. The isolates from bagasse form a strikingly homogeneous group on morphological, biochemical, chemical, nutritional and antibiotic-sensitivity criteria, but cannot be identified unequivocally by using published dichotomous or tabular keys (Williams et al. 1968; Lechevalier \& Lechevalier, 1970; Prauser, 1970; Goodfellow \& Cross, 1974). In their nutrition and ability to degrade a range of compounds they are similar to Nocardia, but they lack nocardomycolic acids, are sensitive to lysozyme, resistant to more antibiotics (Goodfellow \& Orchard, 1974) and have a distinctive morphology. The fine structure of their spores differs from that reported in Nocardia although that of their hyphae is similar. Isolates at present classified as Nocardia autotrophica (Takamiya \& Tubaki) Hirsch differ from other Nocardia species in lacking nocardomycolic acids although they have a type IV wall. Isolates from bagasse differ from this taxon in their characteristic morphology, and their ability to degrade casein and grow on benzoate (Gordon et al. 1974).

Gordona, Micropolyspora, 'Mycobacterium' rhodochrous and Saccharomonospora are also placed in the family Nocardiaceae (Nonomura \& Ohara, 1971 $b$; Cross \& Goodfellow, 1973). The bagasse isolates differed from these in morphology and fine structure, although Micropolyspora species also produce substrate and aerial mycelia but with chains of up to only 20 spores (usually fewer) having smooth, finely toothed or warty surfaces and with prominently thickened end walls. Nocardomycolic acids have been found in Micropolyspora brevicatena but not in Micro. angiospora. It is not known whether they occur in other Micropolyspora species.

Bacterionema, Mycobacterium, and Pseudonocardia also have type IV walls, but the first two produce at most a transient substrate mycelium, no aerial mycelium or spores, and differ in many other respects from the bagasse organism. Pseudonocardia has a stable mycelium and distinctive morphology.

Saccharopolyspora hirsuta isolates resemble Actinomadura, especially $A$. dassonvillei, in morphology, fine structure, nutrition and hydrolytic abilities, but differ in wall composition. There was less affinity with $A$. madurae (Vincent) Lechevalier \& Lechevalier and $A$. pelletieri (Laveran) Lechevalier \& Lechevalier, which were only loosely associated with $A$. dassonvillei by numerical taxonomy (Goodfellow, 197I). We do not know enough of the new species described by Nonomura \& Ohara (I97I $c$ ) to assess their relationships with other Actinomadura species.

The isolates from bagasse have affinities with species of Nocardia and Actinomadura and their classification depends on the emphasis placed on the various groups of characters. Unless Nocardia and Actinomadura are reunited (Krassilnikov, 1970; Gordon et al. 1974) it does not seem advisable to include the bagasse isolates in either genus. We prefer the dangers of 'splitting' rather than accept the alternative of 'lumping' the species into a heterogeneous taxon, especially as Nocardia has only recently ceased to be a 'taxon of convenience' for difficult isolates (Cross \& Goodfellow, 1973). Chemical criteria should not outweigh other taxonomic criteria although they have recently helped improve classification 
(Lechevalier et al. 1973). These conclusions would make it inadvisable to include organisms with different types of wall in the same genus. The bagasse isolates form a homogeneous group distinguishable from other taxa by several unrelated criteria. Because Saccharopolyspora gen. nov. is aerobic, has fragmenting vegetative mycelium, aerial mycelium forming spores, and type IV walls, the genus should be classified in the family Nocardiaceae (Lechevalier \& Lechevalier, 1970; Prauser, 1970; Cross \& Goodfellow, 1973).

We are grateful to Dr Ruth E. Gordon for her interest and for letting us see unpublished results. We thank Miss D. H. Williams, Ms. G. Alderson and Mr L. Al-Shamaony for their help and Mrs S. Roberts, Mr P. Jones and Mr R. H. Turner for electron microscopy.

\section{REFERENCES}

Becker, B., Lechevalier, M. P. \& LeChevalier, H. A. (1965). Chemical composition of cell-wall preparations from strains of various form-genera of aerobic actinomycetes. Applied Microbiology r3, 236-243.

Corbaz, R., Gregory, P. H. \& Lacey, M. E. (1963). Thermophilic and mesophilic actinomycetes in mouldy hay. Journal of General Microbiology 32, 449-455.

Cross, T. \& Goodfellow, M. (1973). Taxonomy and classification of the actinomycetes. In Actinomycetales: Characteristics and Practical Importance. Society for Applied Bacteriology Symposium Series, No. 2, I I-I I 2. Edited by G. Sykes and F. A. Skinner. London: Academic Press.

Cross, T., MACiver, A. M. \& LACEY, J. (1968). The thermophilic actinomycetes in mouldy hay: Micropolyspora faeni $\mathrm{sp}$. nov. Journal of General Microbiology 50, 35I-355.

GledHILL, W. E. \& CASIDA, L. E. (1969). Predominant cantalase-negative soil bacteria. III. Agromyces gen. n., micro-organisms intermediary to Actinomyces and Nocardia. Applied Microbiology 18, 340-349.

Goodfellow, M. (1971). Numerical taxonomy of some nocardioform bacteria. Journal of General Microbiology 69, 33-80.

Goodfellow, M. \& Cross, T. (1974). Actinomycetes. In Biology of Plant Litter Decomposition, vol. 2, pp. 269-302. Edited by C. H. Dickinson and G. J. F. Pugh. London: Academic Press.

Goodfellow, M., Fleming, A. \& SaCkin, M. J. (1972). Numerical classification of 'Mycobacterium' rhodochrous and Runyon's group IV mycobacteria. International Journal of Systematic Bacteriology 22, $8 \mathrm{I}-98$.

Goodfellow, M., Lind, A., Mordarska, H., Pattyn, S. \& Tsukamura, M. (1974). A co-operative numerical analysis of cultures considered to belong to the 'rhodochrous' complex. Journal of General Microbiology $85,29 \mathrm{I}-302$.

Goodfellow, M., Minnikin, D. E., Patel, P. V. \& Mordarska, H. (1973). Free nocardomycolic acids in the classification of nocardias and strains of the 'rhodochrous' complex. Journal of General Microbiology 74, $185-188$.

Goodfellow, M. \& ORChARd, V. A. (1974). Antibiotic sensitivity of some nocardioform bacteria and its value as a criterion for taxonomy. Journal of General Microbiology 83, 375-387.

Gordon, R. E. (1967). The taxonomy of soil bacteria. In Ecology of Soil Bacteria, pp. 293-321. Edited by T. R. G. Gray and D. Parkinson. Liverpool: Liverpool University Press.

Gordon, R. E., Barnett, D. A., Handerhan, J. E. \& PANG, C. H. N. (1974). Nocardia coeliaca, Nocardia autotrophica, and the nocardin strain. International Journal of Systematic Bacteriology 24, 54-63.

Gregory, P. H. \& LACEY, M. E. (I963). Mycological examination of dust from mouldy hay associated with farmer's lung disease. Journal of General Microbiology 30, 75-88.

KrassilniKov, N. A. (1970). Ray-fungi-Higher Forms. Moscow: Izedatelstvo 'Nauka'.

LACEY, J. (197I a). The microbiology of moist barley storage in unsealed silos. Annals of Applied Biology 69, I $87-2 \mathrm{I} 2$.

LACEY, J. (I97I $b$ ). Thermoactinomyces sacchari sp. nov., a thermophilic actinomycete causing bagassosis. Journal of General Microbiology 66, 327-338.

LACEY, J. (1974). Moulding of sugar-cane bagasse and its prevention. Annals of Applied Biology 76, 63-67.

LACEY, J. \& VINCE, D. A. (197I). Endospore formation and germination in a new Thermoactinomyces species. In Spore Research I97I, pp. 18r-188. Edited by A. N. Barker, G. W. Gould and J. Wolf. London: Academic Press. 
Lechevalier, H. A. \& Lechevalier, M. P. (1970). A critical evaluation of the genera of aerobic actinomycetes. In The Actinomycetales, pp. 393-405. Edited by H. Prauser. Jena: Gustav Fischer.

Lechevalier, M. P., Lechevalier, H. \& Horan, A. C. (1973). Chemical characteristics and classification of nocardiae. Canadian Journal of Microbiology 19, 965-972.

Minnikin, D. E., Patel, P. V. \& Goodfellow, M. (1974). Mycolic acids of representative strains of Nocardia and the 'rhodochrous' complex. FEBS Letters 39, 322-324.

Mordarska, H., Mordarski, M. \& Goodfellow, M. (I972). Chemotaxonomic characters and classification of some nocardioform bacteria. Journal of General Microbiology 71, 77-86.

Nonomura, H. (1974). Key for classification and identification of species of rare actinomycetes isolated from soils in Japan. Journal of Fermentation Technology 52, 71-77.

Nonomura, H. \& Ohara, Y. (I97I $a$ ). Distribution of actinomycetes in soil. VIII. Green-spore group of Microtetraspora, its preferential isolation and taxonomic characteristics. Journal of Fermentation Technology 49, I-7.

Nonomura, H. \& Ohara, Y. (I97I $b$ ). Distribution of actinomycetes in soil. XV. New genus and species of monosporic actinomycetes. Journal of Fermentation Technology 49, 895-903.

Nonomura, H. \& Ohara, Y. (I97I $c$ ). Distribution of actinomycetes in soil. XI. Some new species of the genus Actinomadura Lechevalier et al. Journal of Fermentation Technology 49, 904-9I 2.

Prauser, H. (1970). Characters and genera arrangement in the Actinomycetales. In The Actinomycetales, pp. 407-418. Edited by H. Prauser. Jena: Gustav Fischer.

Pridham, T. G., Anderson, P., Foley, C., Lindenfelser, L. A., Hesseltine, C. W. \& Benedict, R. G. (I957). A selection of media for the maintenance and taxonomic study of Streptomyces. Antibiotics Annual 1956/57, 947-953.

Pridham, T. G. \& Lyons, S. J. (I96I). Streptomyces albus (Rossi-Doria) Waksman et Henrici: taxonomic study of strains labelled Streptomyces albus. Journal of Bacteriology 8I, 43 I-44I.

Ridgway, R. (I9I 2). Color Standards and Color Nomenclature. Washington: R. Ridgway.

Williams, S. T., Davies, F. L. \& Cross, T. (I968). Identification of genera of the actinomycetales. In Identification Methods for Microbiologists, B. Society of Applied Bacteriology Technical Series No. 2, pp. I I I-2 I4. Edited by B. M. Gibbs and D. A. Shapton. London: Academic Press. 